\title{
A conceptual dynamic vegetation-soil model for arid and semiarid
}

\section{zones}

\author{
D. I. Quevedo ${ }^{1}$ and F. Francés ${ }^{1}$ \\ ${ }^{1}$ Institute for Water Engineering and Environment, Polytechnical University of Valencia, Spain
}

Received: 16 August 2007 - Published in Hydrol. Earth Syst. Sci. Discuss.: 25 September 2007

Revised: 1 August 2008 - Accepted: 14 August 2008 - Published: 10 September 2008

\begin{abstract}
Plant ecosystems in arid and semiarid climates show high complexity, since they depend on water availability to carry out their vital processes. In these climates, water stress is the main factor controlling vegetation development and its dynamic evolution.

The available water-soil content results from the water balance in the system, where the key issues are the soil, the vegetation and the atmosphere. However, it is the vegetation, which modulates, to a great extent, the water fluxes and the feedback mechanisms between soil and atmosphere. Thus, soil moisture content is most relevant for plant growth maintenance and final water balance assessment.

A conceptual dynamic vegetation-soil model (called HORAS) for arid and semi-arid zones has been developed. This conceptual model, based on a series of connected tanks, represents in a way suitable for a Mediterranean climate, the vegetation response to soil moisture fluctuations and the actual leaf biomass influence on soil water availability and evapotranspiration. Two tanks were considered using at each of them the water balance and the appropriate dynamic equation for all considered fluxes. The first one corresponds to the interception process, whereas the second one models the evolution of moisture by the upper soil. The model parameters were based on soil and vegetation properties, but reduced their numbers.
\end{abstract}

Simulations for dominant species, Quercus coccifera L., were carried out to calibrate and validate the model. Our results show that HORAS succeeded in representing the vegetation dynamics and, on the one hand, reflects how following a fire this monoculture stabilizes after 9 years. On the other hand, the model shows the adaptation of the vegetation to the variability of climatic and soil conditions, demonstrating that in the presence or shortage of water, the vegetation regulates

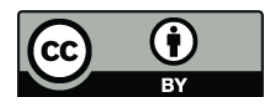

Correspondence to: D. I. Quevedo (diaquete@doctor.upv.es) its leaf biomass as well as its rate of transpiration in an attempt to minimize total water stress.

\section{Introduction}

Water-controlled ecosystems are complex, evolving structures, whose characteristics and dynamic properties depend on many interrelated links between climate, soil and vegetation (Rodriguez-Iturbe et al., 2001). To this end, soil and climate control the vegetation dynamic, while the vegetation modulates the total water balance, being the main link between atmosphere and soil (Porporato and Rodriguez-Iturbe, 2002; Larcher, 2003). Light, nutrients and water are fundamental resources for vegetation development, but in arid and semiarid conditions, water is the major controlling factor. Therefore, in this climatic scenario, soil moisture fluctuation is the key variable in the soil-vegetation-atmosphere continuum (D'Odorico et al., 2000; Rodriguez-Iturbe, 2000; Albertson and Kiely, 2001; Porporato et al., 2001; RodriguezIturbe et al., 2001; Isham et al, 2005).

Due to climate-soil moisture variability in arid and semiarid climates, vegetation has developed adaptation strategies to survive at decreasing or null water availability, for instance grouping in functional types characterized by an optimum use of water resources (Eagleson and Segarra, 1985; Gitay and Noble, 1997; Shugart, 1997; Cantón et al., 2004).

Nowadays, there are many ways to answer the vegetationmodelling question. Most of the hydrological models are able to represent (properly) the hydrological processes at watershed scale, but all of them consider the vegetation as a static parameter. In some cases, hydrologic processes like soil moisture dynamic and bare-soil evaporation, so important in semi-arid and arid ecosystems behaviour, are modelled together due to their close interaction. These approaches, based on energy fluxes and soil properties, are carried out neglecting most of the interactions with vegetation

Published by Copernicus Publications on behalf of the European Geosciences Union. 


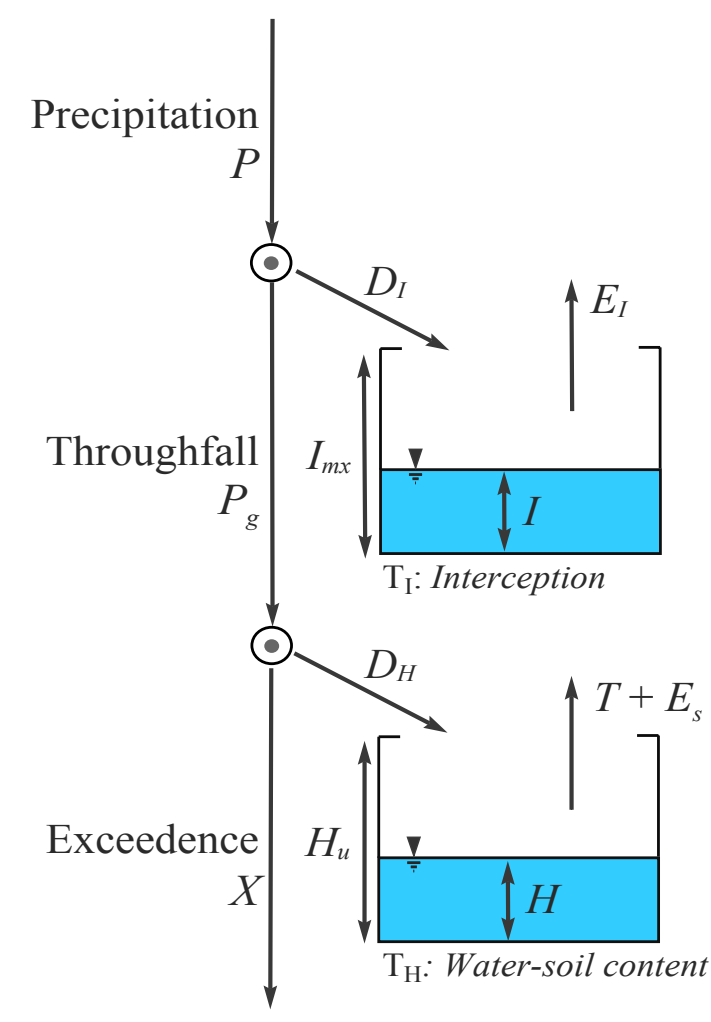

Fig. 1. HORAS model scheme.

and the vegetation dynamic itself (Lee and Pielke, 1992; Parlange and Katul, 1992; Walker and Langridge, 1996; Alvenäs and Jansson, 1997; Snyder et al., 2000; Aydin et al., 2005).

Several models for specific vegetation physiological processes have been developed at plant or vegetation plot scale. Processes like interception (Calder, 1990; Eltahir and Bras, 1993), transpiration (Mackay et al., 2003; Guswa et al., 2004) and the sensibility to water availability (Nouvellon et al., 2000a; Gracia et al., 2003; Mackay et al., 2003; Rosati and Dejong, 2003) are modelled, but with high parameter requirements.

Models designed to simulate agriculture management (ALMANAC: Kiniry et al., 1992; SWAT: Neitsch et al., 2002; SWAP: Kroes and van Dam, 2003) are focused on reproducing crops' growth, irrigation practices, pesticides use and nutrient requirements, but they still need a large amount of data.

Process-based ecosystems models were developed mainly focusing on the simulation of the photosynthesis, autotrophic and heterotrophic respiration, allocation, turnover, mortality, recovery after disturbance (i.e. fire or land-use changes) recovery, plant competition, etc. These models involve the plant physiological processes from regional to global scales, paying special attention to the energy balance and $\mathrm{CO}_{2}$ exchanges to evaluate climate changes (White et al., 2000; Arora and Boer, 2005).
In the same way, the Soil-Vegetation-Atmosphere Transfer schemes (SVAT) were thought to simulate, energy and carbon fluxes. Moreover, these models take into account the water balance, but they still consider static vegetation (Federer, 1979; Dawes et al., 1997; Arora, 2002). To this end, the processes of photosynthesis, respiration from vegetation and soil carbon components, and net carbon uptake computation should be explicit, which means a requirement for too much information.

Finally, to solve the static character of the vegetation, Vegetation Dynamic Models coupled with Land Surface Models (VDM-LSM) have been developed. The VDM-LSMs are physically based models that include the vegetation physiological process as well as the water balance computation, but require a great amount of input data and parameters (Dawes and Hatton, 1993; Mackay and Band, 1997; Cao and Woodward, 1998; Nouvellon et al., 2000b; Arora, 2003; Montaldo et al., 2005).

Therefore, the main aim of our research was to develop a Conceptual Dynamic Vegetation-Soil model (called HORAS), specifically designed for arid and semi-arid ecosystems, with a similar objective to the Montaldo et al. (2005) approach, but with a more parsimonious model in its parameters and input requirements. The resulting model simulates the vegetation response to the soil moisture fluctuations, taking into account the main water fluxes between soil, vegetation and atmosphere. Moreover, leaf biomass evolution was included in the model as a state variable considering the vegetation water demand, water-soil availability and the vegetation water-stress concept.

\section{Model description}

The HORAS model is based on a tank type conceptualization, with two interconnected tanks representing the vegetation interception and the upper part of the soil. The vegetation is assumed to be monoculture (functional vegetation type or dominant specie), considering mature communities and neglecting successional processes. In our model, the state variable related to vegetation is the relative leaf biomass $R$, which is equal to one when vegetation transpiration is at its potential rate when there are no water restrictions, i.e., $R$ is equivalent to the crop coefficient factor used traditionally for the evaluation of the actual evapotranspiration (Allen et al., 1998), but not fixed in time.

Considering the hydrological part of HORAS (Fig. 1), in our model the rainfall $P$ enters the system and a quantity of water $D_{I}$ is derived at the first tank $T_{I}$, which represents the vegetation interception. The amount of water in this tank, interception $I$, is a function of leaf biomass, precipitation and previous interception, and is available to direct evaporation $E_{I}$. The quantity of rainfall that cannot enter $T_{I}$ is considered the throughfall $P_{g}$, and it is able to enter into the second tank $T_{H}$, which represents the capillary storage (below 
field capacity) in the upper part of the soil. The available water-soil content $H$ is the quantity of water stored in $T_{H}$; it depends on soil and vegetation properties, and is available for transpiration $T$ and bare-soil evaporation $E_{S}$ processes. Finally, the amount of water not involved in $T_{I}$ and $T_{H}$ represents the water exceedence $X$, which will be available for percolation and surface runoff.

HORAS only models canopy interception and upper capillary water-soil content, because the main processes related to the vegetation occur there. However, due to its structure, HORAS is easily coupled with any other hydrological model in order to simulate the rest of the hydrologic cycle.

The model time discretization is daily. This has the aim of modelling the vegetation dynamics, the water stress response and the fluctuations of the soil moisture content throughout the year. The model was thought to work with 10 to $100 \mathrm{~m}$ cell sizes, because it makes it possible to model the physiological processes that occur at both individual and set of plant levels, taking into account the hydrological processes scale.

\subsection{Interception and direct evaporation}

As mentioned above, $T_{I}$ represents the water retained by vegetation on the surface of its leaves and stems. The maximum capacity of $T_{I}$ is $I_{m x}$; this depends in general on quantity and intensity of rainfall, leaf biomass and vegetation type. According to the model scheme, $P$ is stored in $T_{I}$ until $I_{m x}$ is reached. Then, $P_{g}$ is defined by:

$$
P_{g}=\max \left[0 ; P-I_{m x} \cdot R+I\right]
$$

The interception of water can be reduced mainly by evaporation or by leaf and stem absorption, but this last way only represents low percentages, so it has been disregarded in HORAS. The water evaporated from interception $E_{I}$ is evaluated by:

$E_{I}=\min [I ; P E T]$

where $P E T$ is the potential evapotranspiration rate. $P E T$ is the simplest and traditional way to represent the energy availability and the atmospheric conditions for evapotranspiration. Therefore, $T_{I}$ is not only needed for an explicit water balance, but also for an implicit energy balance in our model.

\subsection{Upper soil storage and evapotranspiration}

The second storage $T_{H}$ represents the water retained by capillary-soil forces in the upper part of the soil or rooting zone. This storage has a maximum capacity $H_{u}$ function of field capacity $\theta_{f c}$, wilting point $\theta_{w}$ and effective soil depth $z_{e}$. Effective soil depth can be equal to soil depth if the latter is smaller. $P_{g}$ is stored in $T_{H}$ up to $H_{u}$. Then, the water exceedence $X$ is determined by:

$X=\left[0 ; P_{g}-H_{u}+H\right]$
The water in $T_{H}$ can outflow either by $E_{S}$ or by $T$. The evapotranspiration $E T$ represents the sum of water losses by $E_{I}$, $T$ and $E_{S}$. The model gives priority to $T$ instead to $E_{S}$, that is, in the sequence of water extraction from $T_{H}, T$ has the first chance to do it. If we use the $P E T$ traditional concept, the transpiration is computed as:

$T=\min \left[P E T \cdot R \cdot f(\theta) ; P E T-E_{I} ; H\right]$

where $f(\theta)$ is the extraction curve defined below in Eq. (6) and $\theta$ is the upper soil moisture content. $\theta$ is related with available water-soil content $H$ by:

$H=\left(\theta-\theta_{w}\right) \cdot z_{e}$

When $\theta$ is between optimum $\theta^{*}$ and field capacity $\theta_{f c}$ soil moisture contents, $T$ depends on the type of plant (leaf biomass and soil moisture threshold of normal physiological processes), vegetation density and energy and atmospheric conditions (i.e. solar radiation, temperature, relative humidity, etc.). As long as $\theta$ decreases, $\mathrm{T}$ is reduced by stomatal closure to prevent water losses, which continues until $\theta$ reaches the wilting point $\theta_{w}$. The plants are in water stress. This behaviour has been widely studied at both levels: individual plant and plantation scale (Federer, 1979; Cordoba and Bras, 1981; Spittlehouse and Black, 1981; Dingman, 1994; Laio et al., 2001; Daly et al., 2004) and has been demonstrated that can approach to a linear piecewise function, when $\theta^{*}$ determines if the plant is unstressed or not:

$f(\theta)= \begin{cases}1 & \text { for } \theta^{*}<\theta \leq \theta_{f c} \\ \frac{\theta-\theta_{w}}{\theta^{*}-\theta_{w}} & \text { for } \theta_{w}<\theta \leq \theta^{*} \\ 0 & \text { for } \theta \leq \theta_{w}\end{cases}$

In Eq. (4) $T$ is limited by the energy availability and atmospheric conditions, represented by the residual potential evapotranspiration $\left(P E T-E_{I}\right)$, and the water availability in the upper part of the soil, represented by $H$.

The bare-soil evaporation process is restricted to the area not covered by vegetation (approximated by $1-R$ ) and is considered to take place into a soil surface layer with the same soil properties and $\theta$ than rooting zone, but with a depth $z_{s s}$ much smaller than $z_{e}$. The $E_{s}$ process is limited by a second residual potential evapotranspiration $\left(P E T-E_{I}-T\right)$ and is computed by:

$E_{s}=\min \left[H \cdot\left(\frac{z_{s s}}{z_{e}}\right) \cdot(1-R) ; P E T-E_{1}-T\right]$

\subsection{Dynamic vegetation modelling}

In spite of the fact that vegetation growth requirements are dependant on light, water and nutrients, in semiarid and arid environments, the vegetation is highly conditioned to the availability of water to carry out vital processes. To represent this dependency, the model considers for the seasonal variation of $R$ with time on a daily basis: 


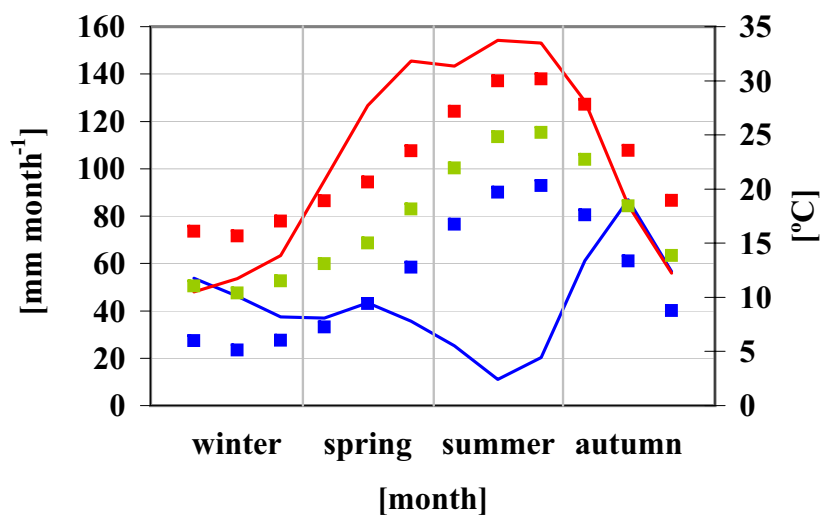

$\longrightarrow P-P E T \backsim T m d \backsim T m x=T m n$

Fig. 2. Mean monthly climatic conditions extracted from Manises (precipitation) and Forn d'Alcedo (temperature) stations, recorded from 1 August 1966 to 31 December 2001.

1. The increase of $R$ is a function of the transpiration rate per unit of vegetation biomass $(T / R)$, following the Water Use Efficiency concept (Larcher, 2003; Daly et al., 2004; Rodriguez-Iturbe and Porporato, 2004).

2. The decrease of $R$ is proportional to $R$ and a function of a leaf-shedding rate (obvious) and water stress (Porporato et al., 2001; Neitsch et al., 2002; Kroes and van Dam, 2003).

Therefore, the proposed expression for the vegetation evolution is:

$\frac{d R}{d t}=\left(\frac{A_{n, m x}}{B_{p o t}}\right) \cdot\left(\frac{T}{T_{m x} \cdot R}\right)^{c}-k \cdot(1+\zeta) \cdot R$

where $A_{n, m x}$ is maximum net assimilation, $B_{p o t}$ is leaf potential biomass, $T_{m x}$ is maximum transpiration rate, $c$ is a shape exponent, $k$ is leaf-shedding rate (it can be different throughout the year), and $\zeta$ is water stress. The last one is calculated by the expression proposed by Porporato et al. (2001) as a function of the soil moisture $\theta$ :

$\zeta=\left\{\begin{array}{cl}{\left[\frac{\theta^{*}-\theta}{\theta^{*}-\theta_{w}}\right]^{q}} & \text { for } \quad \theta_{w} \leq \theta \leq \theta^{*} \\ 0 & \text { for } \theta>\theta^{*}\end{array}\right.$

where $q$ is a measure of nonlinear effects of soil-moisture deficit on plant conditions. Below $\theta^{*}$, the plant stars being stressed; below $\theta_{w}$, the plant cannot extract more water and can suffer damage on its tissues.

\section{Model application}

HORAS model was applied to a Mediterranean semiarid slope covered by kermes oak specie (Quercus coccifera $\mathrm{L}$.). The kermes oak is an evergreen sclerophyllous shrub, which covers extensive areas of Mediterranean garrigue in Mediterranean watershed (Le Houérou, 1981). Quercus coccifera L. inhabits regions where the edaphic conditions lead to a great aridity and is considered pyrostable, since it shows a high regeneration rate after fire. The latter, seems to be due to the continuity of belowground biomass after fire that plays an important role in determining the optimum tactics to be adopted during succeeding cycles (Abril and Gracia, 1989; Cañellas and San Miguel, 2000; Delitti et al., 2005). The kermes oak is found commonly in Spain in continental vegetation structure in the meso-Mediterranean belt and varied ombrotype climates (dry-humid, semiarid-dry, drysubhumid and dry) reaching up to $2 \mathrm{~m}$ in height. It is also found in coastal formation in the thermo-Mediterranean belt and in several ombrotype climates (semiarid-humid, dry, drysubhumid and semiarid), where it covers $75 \%$ of terrain. In this formation, the kermes impedes the development of herb substrate, reaching no more than $1 \mathrm{~m}$ in height. Sanchis et al. (2003) has pointed out that the kermes oak specie is able to live in soils with any kind of chemical characteristics, but it is very frequently found in soils with low depth, over Chromic Luvisols ("terras rossas").

\subsection{Data series}

The meteorological data are taken from two stations belonging to the Spanish National Meteorological Institute. The first station, Manises, is located in the Southwest of Valencia city (latitude $39^{\circ} 25^{\prime} 30^{\prime \prime} \mathrm{N}$, longitude $0^{\circ} 26^{\prime} 17^{\prime \prime} \mathrm{W}$, altitude $30 \mathrm{~m}$ a.s.1.) and monitors mean, maximum and minimum daily temperature. The second station, Forn d'Alcedo, is situated close to the previous one (latitude $39^{\circ} 29^{\prime} 22^{\prime \prime} \mathrm{N}$, longitude $0^{\circ} 28^{\prime} 16^{\prime \prime} \mathrm{W}$, altitude $57 \mathrm{~m}$ a.s.l.) and monitors only precipitation. The climatic conditions correspond to the upper thermo-Mediterranean belt and dry ombrotype, according to Rivas-Martinez (1983) bioclimatic classification.

The observation period for both stations was from 1 January 1966 to 31 December 2001. During the recorded period, the mean annual precipitation was $517 \mathrm{~mm}$. During the first 25 years, annual precipitation regime oscillated between humid to dry conditions, with three years specially humid: 1969 $(794 \mathrm{~mm}), 1971(1133 \mathrm{~mm})$ and $1989(1158 \mathrm{~mm})$. In addition, three years were particularly dry $(1978$ with $273 \mathrm{~mm}$, 1981 with $270 \mathrm{~mm}$ and 1983 with $271 \mathrm{~mm}$ ), but the driest period has been recorded from 1992 to 2000 (mean total precipitation below $500 \mathrm{~mm}$ ). During the year, the mean total precipitation is near to $131 \mathrm{~mm}$ during the winter; decreasing to $108 \mathrm{~mm}$ in the spring season and decreasing further to $80 \mathrm{~mm}$ during the summer, after which $P$ increases to $197 \mathrm{~mm}$ in autumn (see Fig. 2).

The recorded period was characterized by non-extreme temperatures: a winter season with the mean monthly temperature varying between 5 and $17^{\circ} \mathrm{C}$; a warm summer season with the mean monthly temperature oscillating between 19 and $30^{\circ} \mathrm{C}$; and spring and autumn seasons with mean 
Table 1. Soil and vegetation parameters and physical characteristics for the case study (loamy sand and Quercus coccifera L.).

\begin{tabular}{|c|c|c|c|c|}
\hline Parameter & Physical characteristic & Description & Value & Source $^{a}$ \\
\hline & $C_{L A I}, \mathrm{~mm}$ & Interception capacity by unit of $L A I$ & 0.15 & 1 \\
\hline & $C_{S A I}, \mathrm{~mm}$ & Interception capacity by unit of $S A I$ & 0.15 & 1 \\
\hline & $L A I_{m x}$, dimensionless & Maximum leaf area index & 6 & 1 \\
\hline & $S A I_{m x}$, dimensionless & Maximum stem area index & 0.7 & 1 \\
\hline$I_{m x}, \mathrm{~mm}$ & & Maximum interception & 1.0 & Eq. (11) \\
\hline$k$, day $^{-1}$ & & Leaf shedding & $0.0018-0.0024$ & $2 ; 3$ \\
\hline$T_{m x}, \mathrm{mmday}^{-1}$ & & Maximum transpiration rate & 4.7 & 4 \\
\hline$A_{n, m x}, \mathrm{t} \mathrm{ha}^{-1}$ year $^{-1}$ & & Maximum net assimilation carbon & 5.7 & 4 \\
\hline$B_{\text {pot }}, \mathrm{tha}^{-1}$ & & Potential leaf biomass & 6 & 5 \\
\hline$c$, dimensionless & & Shape exponent & 0.03338 & cal \\
\hline$z_{e}, \mathrm{~mm}$ & & Effective soil depth & 400 & obs \\
\hline \multirow[t]{5}{*}{$z_{s s}, \mathrm{~mm}$} & & Soil surface depth & 50 & obs \\
\hline & $\psi_{a e}, \mathrm{MPa}$ & Aeration pressure & $1.74 \mathrm{E}-04$ & 6 \\
\hline & $b$, dimensionless & Porosity distribution index & 4.38 & 6 \\
\hline & $\phi$, dimensionless & Porosity & 0.41 & 6 \\
\hline & $\psi^{*}, \mathrm{MPa}$ & Optimum water potential & 0.03 & 7 \\
\hline \multirow[t]{5}{*}{$H^{*}, \mathrm{~mm}$} & & Optimum available water-soil content & 50.6 & Eq. (10) \\
\hline & $\psi_{f c}, \mathrm{MPa}$ & Field capacity water potential & 0.015 & 8 \\
\hline & $H_{f c}, \mathrm{~mm}$ & Field capacity water-soil content & 59.3 & Eq. (10) \\
\hline & $\psi_{w}, \mathrm{MPa}$ & Wilting water potential & 3 & 7 \\
\hline & $H_{w}, \mathrm{~mm}$ & Wilting water-soil content & 17.7 & Eq. (10) \\
\hline$H_{u}, \mathrm{~mm}$ & & Maximum available water-soil content & 41.6 & \\
\hline$q$, dimensionless & & Nonlinearity effect exponent & 1 & 7 \\
\hline
\end{tabular}

${ }^{a}$ Sources are as follow: 1: Federer (2002); 2: Specht (1988); 3: Castro-Díez and Montserrat-Martí (1998); 4: C. A. Gracia personal communication; 5: Delitti et al. (2005); 6: Clapp and Hornberger (1978); 7: Laio et al. (2001); 8: Larcher (2003); cal: calibrated value; and obs: estimated value from field observations.

monthly temperatures between 12 and $23^{\circ} \mathrm{C}$, both being the optimal seasons for growing vegetation. The mean annual potential evapotranspiration ( $P E T)$ computed with Hargreaves' equation (Allen et al., 1998) was around $1128 \mathrm{~mm}$, which is much larger than the precipitation. During the year, the maximum mean PET was around $430 \mathrm{~mm}$ in summer and the minimum was around $190 \mathrm{~mm}$ in winter, as it is shown in Fig. 2.

\subsection{Parameters estimation}

The parameters of the HORAS model can be separated into soil and vegetation parameters. Soil parameters, as was mentioned before, are related to available water-soil content estimation at different soil moisture contents $\left(\theta^{*}, \theta_{f c}, \theta_{w}\right)$. According to the following soil-water retention curve (Clapp and Hornberger, 1978), $\theta$ can be computed by:

$\psi=\psi_{a e} \cdot\left(\frac{\phi}{\theta}\right)^{b}$

where $\psi_{a e}$ is the aeration pressure, $b$ is the porosity distribution index and $\phi$ is the porosity. Clapp and Hornberger (1978) experimentally determined the values for $\psi_{a e}$ and $b$ used in this work. Table 1 includes parameters required for Eq. (10) for loamy sand soil texture, which were used in the case study. Lastly, Larcher (2003) reported $0.015 \mathrm{MPa}$ field capacity water potential $\psi_{f c}$ as a representative value in semiarid and arid environments.

Vegetation parameters are related with interception, water stress and relative leaf biomass calculation. Parameters as $A_{n, m x}, B_{p o t}, T_{m x}, k, \psi^{*}, \psi_{w}$ and $I_{m x}$ depend on the specie selected to be modelled. For vegetation in semiarid and arid environment, Corcuera et al. (2002) reported 3.2 MPa wilting water potential $\psi_{w}$ as a point of turgor-loss, whereas Laio et al. (2001) used $3 \mathrm{MPa}$. The last one was used for the HORAS simulations. Quercus coccifera L. leaves fall in spring and continue falling through the summer season and occasionally in autumn (Castro-Díez and Montserrat-Martí, 1998). Specht (1988) indicates $k$ parameter was around 0.00120.0024 day $^{-1}$. In HORAS, $k$ was set to 0.0018 in winter, summer and autumn, and 0.002 in spring.

For $I_{m x}$ estimation, Federer (2002) proposes a simplified version of Gash model:

$I_{m x}=C_{L A I} \cdot L A I_{m x}+C_{S A I} \cdot S A I_{m x}$

where $C_{L A I}$ and $C_{S A I}$ are the interception capacity by unit of leaf area index and stem area index respectively. The $L A I_{\mathrm{mx}}$ and $S A I_{m x}$ are maximum leaf area index and maximum stem 


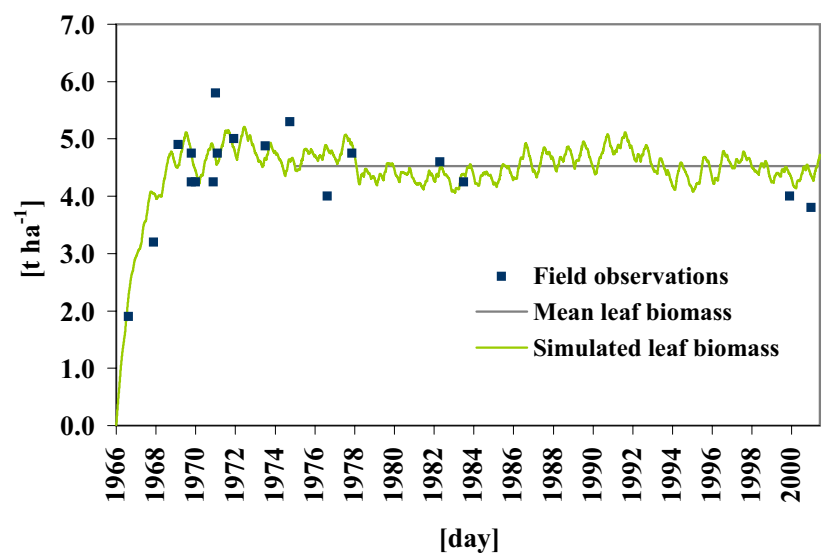

Fig. 3. Daily leaf biomass simulated (continuous line) and mean leaf biomass after stabilisation (horizontal line). Dots are the field observations obtained from Cañellas and San Miguel (2000).

area index respectively. For the Federer (2002) proposed values, the estimated $I_{m x}$ is equal to $1.0 \mathrm{~mm}$.

Table 1 reproduces all the estimated parameters and the physical characteristics needed for their estimation.

\subsection{Calibration of vegetation equation}

Unfortunately, it was not possible from literature to estimate with confidence the parameter $c$, which is the key factor in Eq. (8), since it determines the relationship between vegetation growth and transpiration rate. Therefore, the calibration of this parameter was needed. Although the model time resolution is daily, the objective function for calibration was the root mean square error (RMSE) of annual relative leaf biomass simulated with HORAS, compared with field observations of leaf biomass after a fire (obtained from Cañellas and San Miguel, 2000). Generally, forest fires are in summer and, therefore, the period for the HORAS simulation in the calibrations started on 1 August 1966.

Daily leaf biomass (computed as $R \times B_{\text {pot }}$ ) after calibration, and Cañellas and San Miguel (2000) field observations are showed in Fig. 3. In this figure, the 18 dots (two of them are superimposed) represent Cañellas and San Miguel (2000) field observations. Each of them is the mean value of around 20 measurements of leaf biomass after a fire in different locations in the Province of Valencia (East coast of Spain), with similar soil and climatic conditions (between them and with our case study). HORAS simulations and Cañellas and San Miguel (2000) observations are in good agreement for a $c$ calibrated parameter equal to 0.03338 (with minimum RMSE equal to 0.49 and Nash-Sutcliffe efficiency index of 0.64), as it is showed in Fig. 3. Younger communities show maximal development until 6-8 years, reaching $5.6 \mathrm{tha}^{-1}$ on average $\left(4.8 \mathrm{tha}^{-1}\right.$ in the calibrated model); the six oldest communities show a leaf biomass stabilization around $3.5 \mathrm{tha}^{-1}\left(4.5 \mathrm{tha}^{-1}\right.$ in the calibrated model).
Table 2. Set of Landsat images used for the validation process.

\begin{tabular}{lrrrr}
\hline Date & Satellite & Sensor & Path/Row & $\begin{array}{r}\text { Pixel } \\
\text { resolution }\end{array}$ \\
\hline 29 July 1976 & L1 & MSS & $214 / 032$ & $60 \mathrm{~m}$ \\
24 March 1978 & L2 & MSS & $214 / 033$ & $60 \mathrm{~m}$ \\
19 July 1984 & L5 & TM & $199 / 033$ & $30 \mathrm{~m}$ \\
11 January 1985 & L5 & TM & $199 / 033$ & $30 \mathrm{~m}$ \\
13 August 1987 & L5 & TM & $199 / 033$ & $30 \mathrm{~m}$ \\
06 September 1990 & L5 & TM & $199 / 033$ & $30 \mathrm{~m}$ \\
20 April 1992 & L5 & TM & $199 / 033$ & $30 \mathrm{~m}$ \\
29 January 2000 & L5 & TM & $199 / 033$ & $30 \mathrm{~m}$ \\
08 June 2001 & L5 & TM & $199 / 033$ & $30 \mathrm{~m}$ \\
\hline
\end{tabular}

\subsection{HORAS model validation}

The HORAS model was validated against the Normalized Difference Vegetation Index (NDVI) obtained from nine Landsat images. Two of them come from Multi-spectral Scanner (MSS), and the rest of them from Thematic Mapper (TM) sensors. The images considered are distributed between July 1976 and June 2001 (Table 2). The validation process included intra-annual and inter-annual analysis, since images are available from different seasons and several years.

Geometric and radiometric corrections were performed using ground control points, and the respective sun angle and date. Then, the NDVI was computed. The NDVI is widely used as a remote sensing indicator for green vegetation cover and it is calculated by the following expression:

$N D V I=\frac{\rho_{N I R}-\rho_{R e d}}{\rho_{N I R}+\rho_{R e d}}$

where $\rho_{N I R}$ and $\rho_{\text {Red }}$ are near infrared and red reflectance respectively. The NDVI varies between -1 and 1 . Carlson and Ripley (1997) pointed out three thresholds to NDVI interpretation: $N D V I<0.2$ means predominance of bare soil, between 0.2 and $0.5 \mathrm{mix}$ of bare soil and vegetation, and $N D V I>0.5$ mainly vegetation. The $N D V I$ values are of special interest in the validation process, because they have been related satisfactorily with leaf chlorophyll content, leaf water content, absorbed photosynthetic active radiation, vegetation net production, leaf area index, rainfall, vegetation phenology dynamic and potential evapotranspiration (Chuvieco, 2002). In fact, several studies have been carried out in order to find the correlation between vegetation biomass and NDVI (Escandón et al., 1999; Bader, 2000; Chirici et al., 2007).

Four-shrub land plots were selected from the images, all of them located in the upper part of the Rambla del Poyo watershed, which is also close to Valencia city. The size of the plots varies from 6000 to $37000 \mathrm{~m}^{2}$. Land cover change in this watershed was analysed by Pascual (2001), from this study, it was possible to confirm that since 1956 fires had not affected these plots. The observed NVDIs are highly 


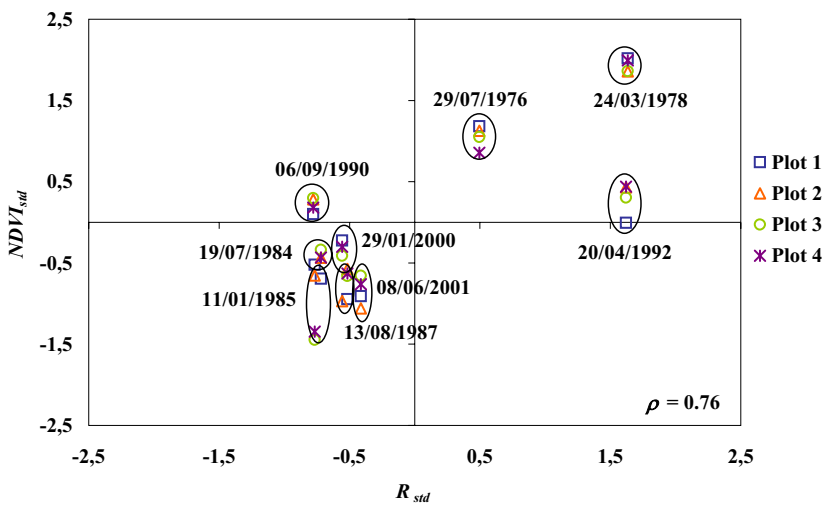

Fig. 4. Scatter plot of standardized Normalized Differenced Vegetation Index $\left(N D V I_{s t d}\right)$ versus standardized relative leaf biomass $\left(R_{\text {std }}\right)$.

variable in all plots. This response can only be related to the soil moisture temporal variability. Higher values of $N D V I$ were preceded by rainy periods, while low values coincide with previous drought spells. The HORAS model reproduces this behaviour quite well, with a correlation of 0.76 . Figure 4 shows the NDVI versus the relative leaf biomass $R$, both standardized by the mean and standard deviation at each plot. The graph shows clearly a positive correlation (first and third quadrants) between measured NDVI and simulated $R$. Only one result is located outside the first or third quadrants, which could be related with some not significant rainfall events which occurred just before and during the day the image was acquired. These events did not produce a significant increase in relative leaf biomass, but they may disguise the actual vegetation appearance. Consequently, it is likely that related $N D V I$ was overestimated.

\section{Soil-vegetation system response}

In order to understand the soil-vegetation system response, a sensitive analysis of the main HORAS state variables (i.e. transpiration $T$, bare-soil evaporation $E_{S}$, available watersoil content $H$, water stress $\zeta$ and relative leaf biomass $R$ ) has been performed considering changes of soil (type and depth) and climatic conditions (mean precipitation and mean $P E T$ ). The case study parameters (Table 1) and inputs (Fig. 2) are fixed as the basic scenario, and changes $\pm 30 \%$ have been done for effective soil depth, precipitation and potential evapotranspiration. With regard to soil type, eleven soil types and their respective soil-water retention curve parameters have been considered (Table 3 ).

In all considered scenarios, the 36 years of climatic data were simulated and the initial conditions were: $R$ equal to 0.76 (mean value for the basic scenario); null interception $I$; and $H$ at field capacity. Table 4 summarizes mean values of
Table 3. Soil characteristics needed by Eq. 10 for eleven different soil textures. Source: Clapp and Hornberger (1978).

\begin{tabular}{llll}
\hline Soil texture & $\psi_{a e}[\mathrm{MPa}]$ & $\phi[-]$ & $b[-]$ \\
\hline Sand, S & $3.42 \mathrm{E}-04$ & 0.395 & 4.05 \\
Loamy sand, LS & $1.74 \mathrm{E}-04$ & 0.41 & 4.38 \\
Sandy clay loam, SCL & $8.43 \mathrm{E}-04$ & 0.42 & 7.12 \\
Sandy clay, SC & $6.02 \mathrm{E}-04$ & 0.426 & 10.4 \\
Sandy loam, SL & $7.01 \mathrm{E}-04$ & 0.435 & 4.9 \\
Loam, L & $1.43 \mathrm{E}-03$ & 0.451 & 5.39 \\
Clay loam, CL & $3.53 \mathrm{E}-03$ & 0.476 & 8.52 \\
Silty clay loam, SiCL & $1.43 \mathrm{E}-03$ & 0.477 & 7.75 \\
Clay, C & $1.82 \mathrm{E}-03$ & 0.482 & 11.40 \\
Silt loam, SiL & 5.53E-03 & 0.485 & 5.30 \\
Silty clay, SiC & $1.70 \mathrm{E}-03$ & 0.492 & 10.40 \\
\hline
\end{tabular}

inputs and state variables (fluxes and storages) for the basic scenario.

Figure 5 shows the behaviour of the main state variables due to the proposed changes. Details are explained in the next paragraphs.

\subsection{Soil types}

Figure 5a shows the variations of the main state variables due to changes in soil texture. Different soil types may yield very different levels of the water-soil content corresponding to the same value of water potential $\left(\psi^{*}, \psi_{w}, \psi_{f c}\right)$. In this sense, each soil type in our model modifies the maximum water-soil content $\mathrm{H}_{u}$ and optimum soil moisture content $\theta^{*}$, through the soil-water retention curve (Eq. 10).

Ingelmo et al. (1994, after Ceballos et al., 2002), obtained a positive correlation between $H$ and the silt plus clay fractions. In Fig. 5a, the soil textures with more content of silt and clay (i.e., more water holding capacity) report the greater values of mean $H$, reaching $102 \mathrm{~mm}$ for silt loam (SiL) followed by clay loam (CL) with $74 \mathrm{~mm}$.

In agreement with Wythers et al. (1999), fine-grained soils hold more water than coarse soils and, consequently, $E_{s}$ are larger than in coarse soils. I.e., silt loam soil (SiL) evaporates $137 \mathrm{~mm}$ year $^{-1}$, while the minimum is reached for loamy sand soil (LS) only $71 \mathrm{~mm}$ year $^{-1}$.

Similar behaviour, but with lower sensitivity, was found for $T$ and $R$. The same occurs for $\zeta$, but inverse to the expected. Their behaviour shows how the determination of $H_{u}$ basically a function of $\theta_{f c}, \theta_{w}$ and $\mathrm{z}_{e}$ ) and $\theta^{*}$ are crucially important, both in the water balance and in the study of leaf biomass and water stress.

\subsection{Soil depth}

Figure $5 \mathrm{~b}$ considers changes to the state variables due to variations in the soil depth. In semiarid Mediterranean climates, the limiting factor for $z_{e}$ is the soil depth. For this reason, in 

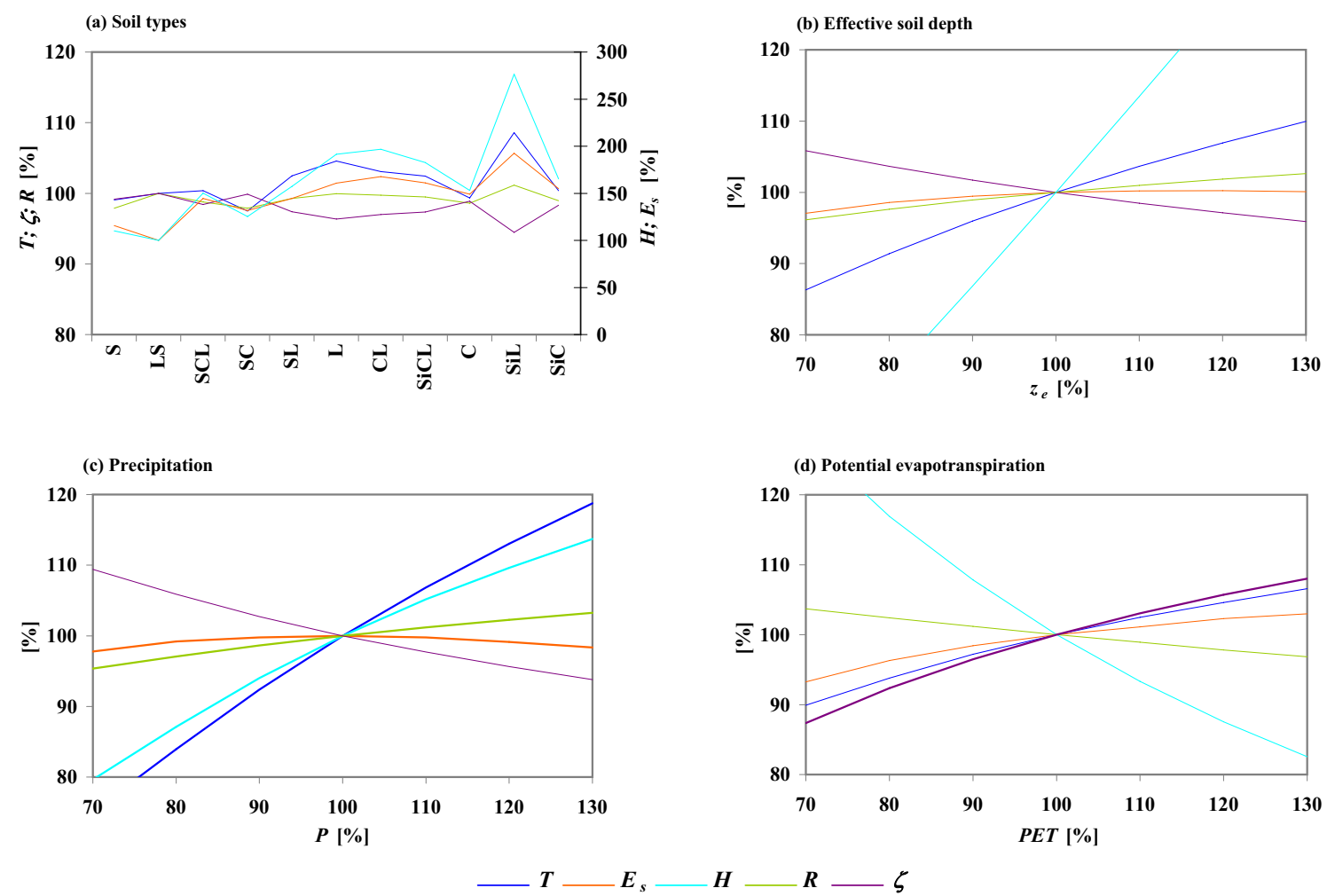

Fig. 5. Sensitivity analysis of main state variables to changes in soil characteristics and mean climatic conditions. The vertical Y-axis is the percentage of transpiration $(T)$, bare-soil evaporation $\left(E_{S}\right)$, available water-soil content $(H)$, relative leaf biomass $(R)$ and water stress $(\zeta)$. The $\mathrm{X}$-axis is the change in soil types (texture), effective soil depth $\left(z_{e}\right)$, mean annual precipitation $(P)$ and mean annual potential evapotranspiration (PET).

Table 4. Mean inputs and state variables for the basic scenario obtained by HORAS simulation from 1 August 1966 to 31 December 2001.

\begin{tabular}{|c|c|c|}
\hline Variable & Description & Mean \\
\hline$P$, mm year $^{-1}$ & Precipitation & 517 \\
\hline$P E T$, mm year $^{-1}$ & Potential evapotranspiration & 1128 \\
\hline$I, \mathrm{~mm}$ & Interception & 0 \\
\hline$E_{I}$, mm year $^{-1}$ & Water-intercepted evaporation & 44 \\
\hline$P_{g}$, mm year $^{-1}$ & Throughfall & 474 \\
\hline$H, \mathrm{~mm}$ & Available water-soil content & 11 \\
\hline$T$, mm year $^{-1}$ & Transpiration & 212 \\
\hline$E_{S}$, mm year $^{-1}$ & Bare-soil evaporation & 71 \\
\hline$X$, mm year $^{-1}$ & Exceedence & 191 \\
\hline$E T$, mm year $^{-1}$ & Evapotranspiration & 326 \\
\hline$R$, dimensionless & Relative biomass & 0.763 \\
\hline$\zeta$, dimensionless & Water stress & 0.677 \\
\hline
\end{tabular}

most cases, changes on soil depth mean the same change in $z_{e}$. In this case, the variation on $z_{e}$ implies changes of $H_{u}$ and the ratio $z_{s s} / z_{e}$. Thus, for loamy sand soil texture, at $-30 \%$ of $z_{e}, H_{u}$ is equal to $29 \mathrm{~mm}$, rising to $54 \mathrm{~mm}$ for $+30 \%$ of $z_{e}$.
Increments of $z_{e}$ are producing increments on mean values of $H, T, R$ and $E_{s}$ and decreases in $\zeta$. The effect on $H$ is larger than the other state variables, as in the case of soil type changes. However, the effect on $E_{s}$ is smaller compared with the soil type changes. This is due to: on the one hand, $z_{e}$ influences directly $H_{u}$ and consequently $H$; on the other hand, positive changes in $H$ imply increments on $R$, diminishing the bare-soil area $(1-R)$ and, therefore, the evaporation from it.

\subsection{Precipitation}

Figure $5 \mathrm{c}$ analyses changes of the model results due to variations on mean precipitation input, but remaining constant in its temporal pattern and the soil parameters from the basic scenario.

As soon as the precipitation rises, $H$ shows a positive response, reaching $13 \mathrm{~mm}$ of daily average. The $H$ increments produce positive changes in $T$ (from 154 to $251 \mathrm{~mm}_{\text {year }}{ }^{-1}$ ), negative changes in $\zeta$ (from 0.635 to 0.740 ) and, as a consequence, increments in $R$ (from 0.727 to 0.788 ). In addition, $T$ is the most sensitive state variable to changes in precipitation. 


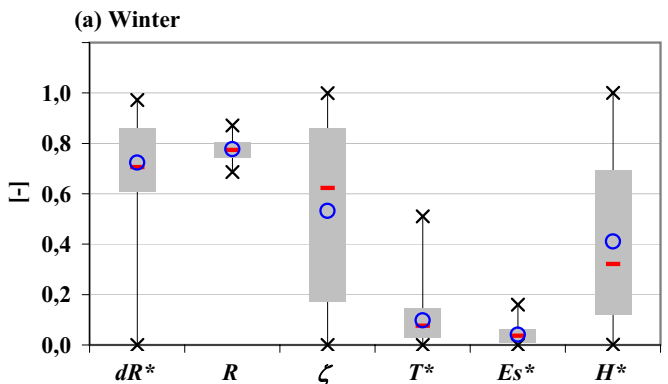

(c) Summer

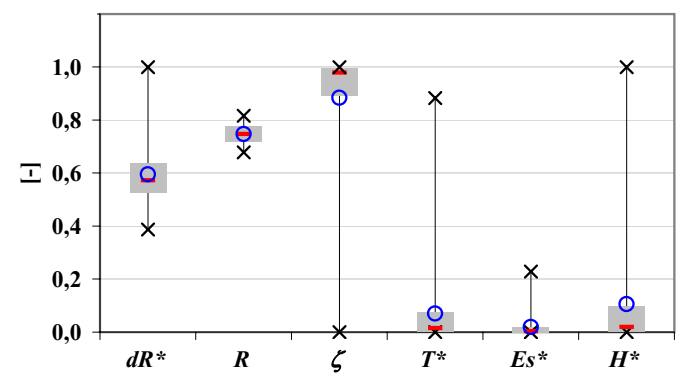

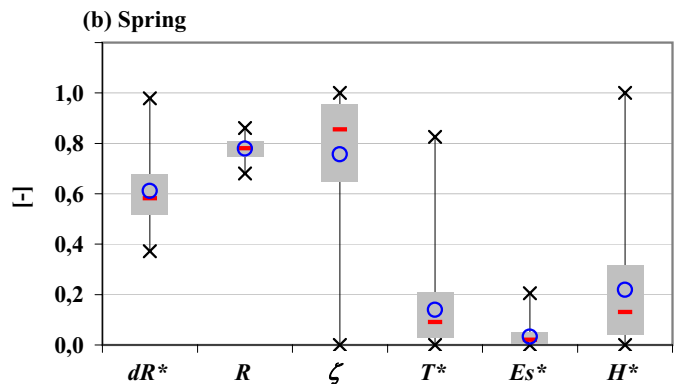

(d) Autumn

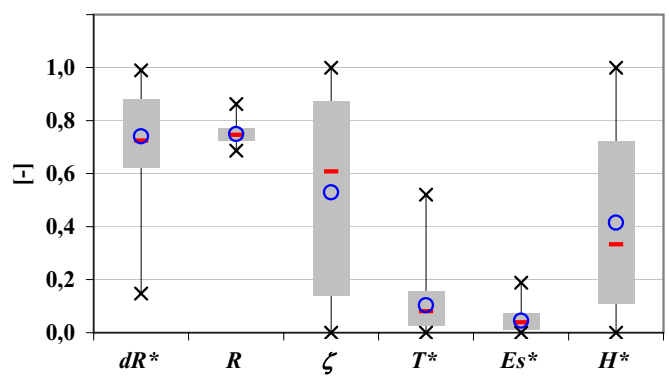

Fig. 6. Box and whisker chart for each season of normalized relative leaf biomass production $\left(d R^{*}\right)$, relative leaf biomass $(R)$, water stress $(\zeta)$, transpiration $\left(T^{*}\right)$, bare-soil evapotranspiration $\left(E_{S}^{*}\right)$ and available water-soil content $\left(H^{*}\right)$. The box represents the 25 th and 75 th percentiles; the symbol (x): minimum and maximum value; the dash (-): median value; and the circle (o): mean value.

$E_{s}$ is not sensitive to changes in $P$. This is due to the fact the increase in soil moisture is compensated for by the decrease in bare-soil area $(1-R)$ and the increment of the days in which the $P E T$ is the limiting factor.

\subsection{Potential evapotranspiration}

Finally, Fig. 5d shows the model sensitivity to changes in $P E T$ input, precipitation and soil characteristics remain constant.

The increment of available energy for evapotranspiration produces increments in $T$ and $E_{s}$. At lower atmospheric demand ( $P E T$ reduction of $30 \%) T$ and $E_{S}$ reduce their rates to 186 and $73 \mathrm{~mm}$ year $^{-1}$ respectively. On the contrary (PET increment of 30\%), they increase up to 219 and $80 \mathrm{~mm}$ year $^{-1}$, respectively.

With respect to $\mathrm{H}$ and $\zeta$, they are more sensitive than $T$ and $E_{S}$ to $P E T$. Looking the whole range of PET, $H$ is reduced from 14 to $9 \mathrm{~mm}$ and $\zeta$ is increased from 0.591 to 0.731 .

Despite the increments in $T$ with $P E T$, there is not an increase in $R$. $R$ changes from 0.791 to 0.739 . I.e., in Eq. (8), the increase on $\zeta$ causes more leaf losses than the increase in leaf production due to the $T$ increments, resulting in a reduction on leaf biomass. Therefore, in a climate change scenario with higher temperatures and higher $P E T$ there will be a significant increase in $T$ but a small decrease in $R$. Also, it is interesting to underline the effect on $R$ is similar with equivalent changes on $P$ and $P E T$.

\section{Model dynamics}

Figure 6 and Table 5 illustrate the model dynamic for parameters and inputs of the basic scenario. Figure 6 shows the box and whiskers chart representing the behaviour of the main state variables (relative leaf biomass production $d R$, relative leaf biomass $R$, water stress $\zeta$, transpiration $T$, baresoil evapotranspiration $E_{S}$ and available water-soil content $H$ ) for each season. Table 5 shows complementary information with monthly mean values of the same state variables showed in Fig. 6. Due to graphical convenience, some variables were normalized to the range 0 to 1 . The $d R$ has been normalized by minimum $(-2.67 \mathrm{E}-03)$ and maximum values of the series $(\max [d R-\min (d R)]$ equal to $4.00 \mathrm{E}-03)$. There will be biomass growth for normalized values between 0.67 and 1, and biomass decrease between 0 a 0.67. $T$ and $E_{s}$ have been normalized by the maximum value of the evapotranspiration $E T$ ( $E T_{m x}$ equal to $6 \mathrm{~mm}$ day $\left.^{-1}\right)$. Finally $H$ by $H_{u}(42 \mathrm{~mm}) . R$ and $\zeta$ already vary between 0 and 1 .

In Fig. 6 it can be seen autumn is the season with more variability, due to the torrential rainfall of this season in Mediterranean climate. In summer, the usual condition is dry, but in the rare rainy days, extreme values can be reached. Water stress and soil moisture show higher variability and 
Table 5. Monthly mean values of relative leaf biomass production $d R$, relative leaf biomass $R$, water stress $\zeta$, transpiration $T$ [mm month $\left.{ }^{-1}\right]$ bare-soil evaporation $E_{S}\left[\mathrm{~mm} \mathrm{month}^{-1}\right]$ and available water-soil content $H$ [mm].

\begin{tabular}{lrrrrrr}
\hline Month & $d R$ & $R$ & $\zeta$ & $T$ & $E_{S}$ & $H$ \\
\hline 1 & $3.37 \mathrm{E}-04$ & 0.772 & 0.446 & 15 & 7 & 19 \\
2 & $2.18 \mathrm{E}-04$ & 0.780 & 0.549 & 17 & 7 & 16 \\
3 & $5.17 \mathrm{E}-05$ & 0.784 & 0.665 & 21 & 7 & 11 \\
4 & $-1.10 \mathrm{E}-05$ & 0.784 & 0.713 & 25 & 6 & 10 \\
5 & $-3.53 \mathrm{E}-04$ & 0.779 & 0.770 & 26 & 6 & 8 \\
6 & $-4.10 \mathrm{E}-04$ & 0.767 & 0.860 & 18 & 4 & 5 \\
7 & $-4.58 \mathrm{E}-04$ & 0.754 & 0.950 & 7 & 1 & 2 \\
8 & $-3.12 \mathrm{E}-04$ & 0.742 & 0.900 & 12 & 3 & 3 \\
9 & $2.31 \mathrm{E}-05$ & 0.737 & 0.741 & 21 & 7 & 9 \\
10 & $2.75 \mathrm{E}-04$ & 0.742 & 0.585 & 23 & 9 & 14 \\
11 & $3.65 \mathrm{E}-04$ & 0.753 & 0.481 & 16 & 8 & 18 \\
12 & $2.99 \mathrm{E}-04$ & 0.762 & 0.457 & 12 & 6 & 19 \\
\hline
\end{tabular}

bare-soil evaporation and leaf biomass are more stable state variables.

In winter (Fig. 6a) the mean value of $H$ is around $40 \%$ of $H_{u}$; as it can be seen in Table 5, December and January are the months with greater available water-soil content. Despite of this situation, mean $T$ and $E_{S}$ are low compared with $E T_{m x}$ (10 and $4 \%$ of $E T_{m x}$, respectively). This result is due to the restriction of a low potential evapotranspiration rate in the winter season. Low variations on $R$ are recorded, remaining around 0.777 , but leaf biomass production records high values in this season (seasonal mean $d R$ equal to $2.26 \mathrm{E}-04$ ). $\zeta$ is most of the time between 0.859 and 0.171 , with a mean value of 0.532 . February records more water stress than January and December, due to $R$ positive variation (Table 5).

Figure $6 \mathrm{~b}$ shows spring results, when temperature and precipitation increase (mean value equal to $38 \mathrm{~mm} \mathrm{month}^{-1}$ ) and vegetation is still growing at high rates. Mean values of $T$ and $R$ are $14 \%$ of $E T_{m x}$ and 0.779 respectively, March and April being the months of the year with more leaf biomass. These increments in $T$ and $R$ with respect to winter values produce mean $H$ falls to $22 \%$ of $H_{u}$ and the mean $\zeta$ rises to 0.860 in June. Mean $E_{s}$ is reduced due to increments in vegetation growing and water-uptake and soil moisture reduction, reaching $4 \mathrm{~mm}$ month $^{-1}$ in late spring (June).

In summer (Fig. 6c), due to shortage of precipitation (11 mm in August) and high temperatures, the vegetation displays a high $\zeta$ most of the time (mean value of 0.884 ; and between 0.892 and $0.99750 \%$ of the days), and $H$ is lower than other seasons achieving $2 \mathrm{~mm}$ in July. The lower value of $H$ implies a reduction in $R$, recording more leaf biomass losses in late summer ( 0.737 in September); concerning $T$ and $E_{S}$, in this season they register lower values than other seasons July being the most critical month. The higher values of PET in this season do not influence the system, the low precipitation being the controlling input in summer.
In autumn (Fig. 6d), precipitation increases (mean value equal to $67 \mathrm{~mm} \mathrm{month}^{-1}$ ) and temperature decreases slowly. According to this, $H$ increases up to $19 \mathrm{~mm}$ in December (late autumn); and mean value of $\zeta$ decreases from 0.884 in summer to 0.529 . The vegetation reactivates its growth with mean value of $R$ equal to 0.750 and consumes more water in the transpiration process, achieving $23 \mathrm{~mm} \mathrm{month}^{-1}$ in the rainiest month (October). Concerning to $E_{s}$, since $H$ increases (increasing the soil moisture), $E_{S}$ increases too, reaching $5 \%$ of $E T_{m x}$.

\section{Conclusions}

This paper presents a Conceptual Vegetation-Soil model based on a tank type schematization. Assuming vegetation leaf biomass must be a state variable instead of a fixed parameter, the objective was to develop a simple model to represent the soil-vegetation-atmosphere dynamic in arid and semiarid zones, such as Mediterranean areas. However, this conceptualization only can be reached by the suitable reproduction of the bi-directional interaction between vegetation and soil moisture.

The proposed dynamic vegetation-soil conceptualization results in a parsimonious model, which can be easily coupled with other complete hydrological or land surface models, at low computational cost. It was proved in the validation stage, that HORAS reproduces well the leaf biomass $R$ development in semiarid and arid zones, using the water stress $\zeta$ as an indicator of plant survival conditions and $T$ as an indicator of leaf biomass growing. It could be concluded that both variables determine the growing season, the water-uptake dynamic and can help to understand the adaptations strategies of the vegetation in case of water shortage.

For Mediterranean semiarid areas with Quercus coccifera L., $T$ is more sensitive to changes in precipitation $P$ and effective soil depth $z_{e}$, while potential evapotranspiration $P E T$ and soil types less influence it; this was expected, since the main restriction in Mediterranean areas is rainfall level and the presence of shallow soils.

Bare-soil evaporation $E_{s}$ shows more dependence on changes in soil types, being insensitive to changes in $z_{e}, P$ and $P E T$. The model reproduces well the $E_{S}$ behaviour in agreement with Wythers et al. (1999), but uses a lower level of parameterization.

The state variable $H$ (or its equivalent soil moisture) is highly sensitive to any type of change, being the connection between all state variables and acting as a regulating factor in the system.

Climatic conditions exert more influence on $\zeta$ than soil properties. In respect to reductions in $z_{e}$, the model shows how the plant in shallow rooting conditions suffers high water stress and, consequently, reduces $T$ and $R$. However, minimum water stress is not enough to define the optimal conditions for the vegetation. 
The model shows $R$ is not highly sensitive to soil parameters and inputs, which means, the Quercus coccifera L. regulates its transpiration in the long term and, a as consequence, the soil moisture content in order to maintain more stable values of $R$. In any case, $R$ shows a certain variation during the year (Table 5), recording its maximum values in March and April and minimum in August. However, the maximum leaf biomass production $d R$ is in November, due to the combination of high precipitation and low potential evapotranspiration. These results are in agreement with what can be observed in nature, because in spring and autumn the vegetation experience optimal conditions of temperature and available water-soil content for growth. In summer, the high temperatures and shortage of water implies a regulation in all vital processes, as transpiration reduction and losses of leaf biomass to stay in optimal conditions.

To summarize, the HORAS model allowed us to study, in a realistic way, the role of active soil depth and soil texture, the effect of plant physiological characteristics and the importance of climatic conditions, in order to understand soil moisture dynamic and water stress behaviour in water-controlled ecosystems.

Acknowledgements. This research has been sponsored by Spanish Research Project CGL2005-06219/HID and by Generalitat Valenciana, Spain, through grant CTBPR B /2004/168.

Edited by: S. Manfreda

\section{References}

Abril, M. and Gracia, C. A.: Crecimiento de los rebrotes de Pistacia lentiscus y Quercus coccifera después de un incendio, in: Options Méditerranéennes: Série A. Séminaires Méditerranéens n. 3, Jornadas sobre las Bases Ecológicas para la Gestión en Ecosistemas Terrestres CIHEAM-IAMZ, edited by: Bellot, J., Zaragoza, 101-106, 1989.

Albertson, J. D. and Kiely, G.: On the structure of soil moisture time series in the context of land surfaces models, J. Hydrol., 243, 101-119, 2001.

Allen, R. G., Pereira, L. S., Raes, D., and Smith, M.: Crop evapotranspiration (guidelines for computing crop water requirements), FAO Irrigation and Drainage Paper, No. 56, 326 pp., 1998.

Alvenäs, G. and Jansson, P.: Model for evaporation, moisture and temperature of bare-soil: calibration and sensitivity analysis, Agr. Forest Meteorol., 88, 47-56, 1997.

Arora, V.: Modeling vegetation as a dynamic component in soilvegetation-atmosphere transfer scheme and hydrological models, Rev. Geophys., 40, 1006, doi:10.1029/2001RG000103, 2002.

Arora, V.: Simulating energy and carbon fluxes over winter wheat using coupled land surface and terrestrial ecosystem models, Agr. Forest Meteorol., 118, 21-47, doi:10.1016/S01681923(3)00073-X, 2003.
Arora, V. K. and Boer, G. J.: A parameterization of leaf phenology for the terrestrial ecosystem component of climate models, Glob. Change Biol., 11, 39-59, doi:10.1111/j.13652486.2004.00890.x, 2005.

Aydin, M., Ynag, S. L., Kurt, N., and Yano, T.: Test of a simple model for estimating evaporation from bare-soils in different environments, Ecol. Model., 182, 91-105, 2005.

Bader, M.: Productivity-biodiversity patterns - a study using multitemporal Landsat TM NDVI data for the Alice Springs region for central Australia, Msc thesis, Wageningen University, The Netherlands, 2000.

Calder, I. R.: Evaporation in the uplands, John Wiley and sons Ltd., Baffins Lane, Chichester, 1990.

Cantón, Y., Solé-Benet, A., and Domingo, F.: Temporal and spatial patterns of soil moisture in semiarid badlands of SE Spain, J. Hydrol., 285, 199-214, doi:10.1111/j.1365-2486.2004.00890.x, 2004.

Cañellas, I. and San Miguel, A.: Biomass of root and shoot systems of Quercus coccifera shrublands in Eastern Spain, Ann. For. Sci., 57, 803-810, 2000.

Cao, M. and Woodward, F. I.: Net primary and ecosystem production and carbon stocks of terrestrial ecosystems and their responses to climate change, Glob. Change Biol., 4, 185-198, 1998.

Carlson, T. and Ripley, D.: On the relation between NDVI, fractional vegetation cover, and leaf area index, Remote Sens. Environ., 62, 241-252, 1997.

Castro-Díez, P. and Montserrat-Martí, G.: Phenological pattern of fifteen mediterranean phanaerophytes from Quercus ilex Communities of NE-Spain, Plant Ecol., 139, 103-112, 1998.

Ceballos, A., Martínez-Fernández, J., Santos, F., and Alonso, P.: Soil-water behaviour of sandy soils under semi-arid conditions in the Duero Basin (Spain), J. Arid. Environ., 51, 501-519, doi:10.1006/jare.2002.0973, 2002.

Chirici, G., Barbati, A., and Maselli, F.: Modelling of Italian forest net primary productivity by the integration of remotely sensed and GIS data, Forest Ecol. Manag., 246, 285-295, 2007.

Chuvieco, E.: Teledetección ambiental - La observación de la Tierra desde el Espacio, Ariel, Barcelona, 2002.

Clapp, R. B. and Hornberger, G. M.: Empirical equations for some soil hydraulic properties, Water Resour. Res., 14, 601-604, 1978.

Cordoba, J. R. and Bras, R. L.: Physically based probabilistic models of infiltration, soil moisture, and actual evapotranspiration, Water Resour. Res., 17, 93-106, 1981.

Corcuera, L., Camarero, J. J., and Gil-Pelegrín, E.: Functional groups in Quercus species derived from the analysis of pressurevolume curves, Trees, 16, 465-472, doi:10.1007/s00468-0020187-1, 2002.

Daly, E., Porporato, A., and Rodriguez-Iturbe, I.: Coupled dynamics of photosynthesis, transpiration, and soil water balance. Part II: Stochastic analysis and ecohydrological significance, J. Hydrometeorol., 5, 559-566, 2004.

Dawes, W. R. and Hatton, T. J.: TOPOG IRM. 1. Model description, Technical Memorandum 93/5, CSIRO Division of Water Resources, Canberra, Australia, 40 pp., 1993.

Dawes, W. R., Zhang, L., Hatton, T. J., Reece, P. H., Beale, G. T. H., and Packer, I.: Evaluation of a distributed parameter ecohydrological model (TOPOG IRM) on a small cropping rotation catchment, J. Hydrol., 191, 64-86, 1997. 
Delitti, W., Ferran, A., Trabaud, L., and Vallejo, V. R.: Effects of fire recurrence in Quercus coccifera L. shrublands of the Valencia region (Spain): I. Plant composition and productivity, Plant Ecol., 177, 57-70, doi:10.1007/s00468-002-0187-1, 2005.

Dingman, S. L.: Physical hydrology, Prentice Hall, New Jersey, 575 pp., 1994.

D’Odorico, P., Ridolfi, L., Porporato, A., and Rodriguez-Iturbe, I.: Preferential states of seasonal soil moisture: The impact of climate fluctuations, Water Resour. Res., 36, 2209-2219, 2000.

Eagleson, P. S. and Segarra, R. I.: Water-limited equilibrium of savanna vegetation systems, Water Resour. Res., 21, 1483-1493, 1985.

Eltahir, E. A. B. and Bras, R. L.: A description of rainfall interception over large areas, J. Climate, 6, 1002-1008, 1993.

Escandón, J. E., de Jong, B. H. J., Ochoa, S., March I., and Castillo, M. A.: Evaluación de dos métodos para la estimación de biomasa arbórea a través de datos Landsat TM en Jusnajab La Laguna, Chiapas, México: estudio de caso, Investigaciones Geográficas, Boletín, num. 40, Instituto de Geografía, UNAM, México, 7184, 1999.

Federer, C. A.: A soil-plant-atmosphere model for transpiration and availability of soil water, Water Resour. Res., 15, 555-562, 1979.

Federer, C. A.: BROOK90 A simulation model for evaporation, soil water, and stream flow documentation for versions 4 and 3.2/3/4, Compass Brook, Durham, New Hampshire, 2002.

Gitay, H. and Noble, I. R.: What are functional types and how should we seek them?, in: Plant functional types: Their relevance to ecosystems properties and global change, International Geosphere-Biosphere Programme Book Series, edited by: Smith, T., M., Shugart, H. H., and Woodward, F. I. , Cambridge University Press, Cambridge, 3-19, 1997.

Gracia, C., Sabaté, S., and Sanchez, A.: GOTILWA+ An integrated model of forest growth, Barcelona University, Spain, 93 pp., 2003.

Guswa, A. J., Celia, M. A., and Rodriguez-Iturbe, I.: Effect of vertical resolution on predictions of transpiration in water-limited ecosystems, Adv. Water Resour., 27, 467-480, doi:10.1016/j.advwatres.2004.03.001, 2004.

Isham, V., Cox, D. R., Rodríguez-Iturbe, I., Porporato, A., and Manfreda, S.: Representation of space-time variability of soil moisture, P. Roy. Soc. A-Math. Phy., 461, 4035-4055, doi:10.1098/rspa.2005.1568, 2005.

Kiniry, J. R., Williams, J. R., Gassman, P. W., and Debaeke, P.: A general, process-oriented model for two competing plant species, T. ASAE, 35, 801-810, 1992.

Kroes, J. G. and van Dam, J. C.: Reference manual SWAP Version 3.0.3, Alterra, Green World Research, Wageningen, 211 pp., 2003.

Laio, F., Porporato, A., Ridolfi, L., and Rodriguez-Iturbe, I.: Plants in water-controlled ecosystems: active role in hydrologic processes and response to water stress - II. Probabilistic soil moisture dynamics, Adv. Water Resour., 24, 707-723, 2001.

Larcher, W.: Physiological plant ecology: Ecophysiological and stress physiology of functional groups, Springer, Berlin, 3 edn., 513 pp., 2003.

Lee, T. J. and Pielke, R. A.: Estimating the soil surface specific humidity, J. Appl. Meteorol., 31, 480-484, 1992.
Le Houérou, H. N.: Impact of man and his animals on Mediterranean vegetation, Ecosystems of the World 11: Mediterraneantype shrublands, edited by: Di Castri, F., Goodall, D. W. and Specht R. L., Elsevier, Amsterdam, 479-521, 1981.

Mackay, D. S. and Band, L. E.: Forest ecosystem processes at the watershed scale: Dynamic coupling of distributed hydrology and canopy growth, Hydrol. Process., 11, 1197-1217, 1997.

Mackay, D. S., Ahl, D. E., Ewers, B. E., Samanta, S., Gower, S. T., and Burrows, S. N.: Physiological tradeoffs in the parameterization of a model of canopy transpiration, Adv. Water Resour., 26, 179-194, 2003.

Montaldo, N., Rodena, R., Albertson, J. D., and Mancini, M.: Parsimonious modelling of vegetation dynamics for ecohydrologic studies of water-limited ecosystems, Water Resour. Res., 41, W10416, doi:10.1029/2005WR004094, 2005.

Neitsch, S. L., Arnold, J. G., Kiniry, J. R., Williams, J. R., and King, K. W.: Soil and water assessment tool theoretical documentation version 2000, Texas Water Resources Institute, College Station, TWRI Report TR-191, Texas, 506 pp., 2002.

Nouvellon, Y., Bégué, A., Moran, M. S., Seen, D. L., Rambal, S., Luquet, D., Chehbouni, G., and Inoue, Y.: PAR extinction in shortgrass ecosystems: Effects of clumping, sky conditions and soil albedo, Agr. Forest Meteorol., 105, 21-41, 2000a.

Nouvellon, Y., Rambal, S., Lo Seen, D., Moran, M. S., Lhomme, J. P., Bégué, A., Chehbouni, A. G., and Kerr, Y.: Modelling of daily fluxes of water and carbon from shortgrasses steppes, Agr. Forest Meteorol., 100, 137-153, 2000b.

Pascual, J. A.: Cambios de usos del suelo y régimen hídrico en la rambla del Poyo y el barranc de Carraixet, PhD Thesis, Valencia University, Valencia, 421 pp., 2001.

Parlange, M. B. and Katul, G. G.: Estimation of the diurnal variation of potential evaporation from a wet bare-soil surface, J. Hydrol., 132, 71-89, 1992.

Porporato, A., Laio, F., Ridolfi, L., and Rodriguez-Iturbe, I.: Plants in water-controlled ecosystems: active role in hydrologic processes and response to water stress - III. Vegetation water stress, Adv. Water Resour., 24, 725-744, 2001.

Porporato, A. and Rodriguez-Iturbe, I.: Ecohydrology - A challenging multidisciplinary research perspective, Hydrolog. Sci. J., 47, 811-822, 2002.

Rivas-Martínez, S.: Pisos bioclimáticos de España, Lazaroa, 5, 3343, 1983.

Rodriguez-Iturbe, I.: Ecohydrology: A hydrology perspective of climate-soil-vegetation dynamics, Water Resour. Res., 36, 3-9, 2000.

Rodriguez-Iturbe, I., Porporato, A., Laio, F., and Ridolfi, L.: Plants in water-controlled ecosystems: Active role in hydrologic processes and response to water stress- I. Scope and general outline, Adv. Water Resour., 24, 695-705, 2001.

Rodriguez-Iturbe, I. and Porporato, A.: Ecohydrology of watercontrolled ecosystems: soil moisture and plant dynamics, Cambridge University Press, Cambridge, 442 pp., 2004.

Rosati, A. and Dejong, T. M.: Estimating photosynthetic radiation use efficiency using incident light and photosynthesis of individual leaves, Ann. Bot.-London, 91, 869-877, doi:10.1016/j.fcr.2004.07.021, 2003.

Sanchis, E., Mariano, M., and Bordón, Y.: Ecosistemas mediterráneos, Valencia Polytechnical University, Valencia, 2003. 
Shugart, H. H.: Plant and ecosystem functional types, in: Plant functional types: Their relevance to ecosystems properties and global change, International Geosphere-Biosphere Programme Book Series, edited by: Smith, T. M., Shugart, H. H., and Woodward, F. I., Cambridge University Press, Cambridge, 2043, 1997.

Snyder, R. L., Bali, K., Ventura, F., and Gómez-MacPherson, H.: Estimating evaporation from bare and nearly bare soil, J. Irrig. Drain. E.-ASCE, 126, 399-403, 2000.

Specht, R. L.: Vegetation, nutrition and climate - Data tables. Natural vegetation - Ecomorphological characters, in: Mediterranean-type ecosystems: A data source book, edited by: Specht, R. L., Kluwer Academic Publishers, Dordrecht, 13-136, 1988.
Spittlehouse, D. L. and Black, T. A.: A growing season water balance model applied to two Douglas fir stands, Water Resour. Res., 17, 1651-1656, 1981.

Walker, B. H. and Langridge, J. L.: Modelling plant and soil water dynamics in semiarid ecosystems with limited site data, Ecol. Model., 87, 153-167, 1996.

White, M. A., Thornton, P. E., Running, S. W., and Nemani, R. R.: Parameterization and sensitivity analysis of the BIOME-BGC terrestrial ecosystem model: net primary production controls, Earth Interac., 4, 1-85, 2000.

Wythers, K. R., Lauenroth, W. K., and Paruelo, J. M.: Bare-soil evaporation under semiarid field conditions, Soil Sci. Soc. Am. J., 63, 1341-1349, 1999. 